\title{
Exposure tests of copper foils in a slurries of different bentonites
}

\section{Expoziční testy měděných folií v suspenzích různých bentonitů}

\author{
Stoulil J. ${ }^{1}$, Kouřil M. ${ }^{1}$, Dobrev D. ${ }^{2}$ \\ ${ }^{1}$ UCT Prague, Department of Metals and Corrosion Engineering \\ ${ }^{2}$ ÚJV Řež, a.s. \\ E-mail: stoulilj@vscht.cz
}

The goal of the study was to compare corrosion performance of copper in different bentonite slurries. Copper coil samples were exposed in a slurries of bentonites BaM, Rokle, B75, G2M, Voltex, Sabenil. The test was carried out under anaerobic conditions in glovebox at laboratory temperature for duration of one to four months. Samples were evaluated by means of X-ray diffraction and mass loss. Liquid parts of slurries were analysed by ion chromatography and $\mathrm{pH}$ meter. The resistance of copper in all studied bentonites was very high. Corrosion rates were in order of tenths of micrometers per year. No trend between pore solution composition and corrosion rate or composition of corrosion products was observed.

\section{INTRODUCTION}

Copper is material believed as corrosion resistant in wet bentonite environment of radioactive waste deep geological repositories. It is candidate material for outer case in Scandinavian concept [1-5] and for coating in Canadian [6-10]. Copper is also one of the candidate materials for construction of canisters in Czech concept [11-18]. In previous works we studied the effect of sulphide content on corrosion rate of copper in bentonite pore solution [18] and simulation of galvanic couple with carbon steel [14].

The aim of this study was to compare behaviour of copper in different bentonites in short-term experiments.

\section{EXPERIMENTAL}

Copper foil of the thickness $100 \mu \mathrm{m}$ and purity 99.97 wt.\% (GoodFellow) was used for samples preparation. Each sample had dimensions $50 \times 300 \mathrm{~mm}$. Six types of bentonite were used as environments: BaM, Rokle, B75, G2M, Voltex and Sabenil. $200 \mathrm{~g}$ of each bentonite was mixed with $1000 \mathrm{ml}$ of demineralised water in $1000 \mathrm{ml}$ glass flask and deaerated for 2 weeks in glovebox by nitrogen (99.99 vol.\%). Part of slurry was deposited on the foils as $1 \mathrm{~mm}$ thick layer and then
Cílem této práce bylo porovnání korozni odolnosti měděných folii v suspenzich různých bentonitů. Cívkové měděné vzorky byly exponovány $v$ suspenzich bentonitu BaM, Rokle, B75, G2M, Voltex, Sabenil. Expozice probihala za anaerobnich podminek v rukavicovém boxu za laboratorni teploty po dobu jednoho a čtyř měsicũ. Vzorky byly hodnoceny pomoci rentgenové difrakce a hmotnostnich úbytkü. Kapalná část suspenzi byla analyzována pomocí iontové chromatografie a měreni $\mathrm{pH}$. Agresivita všech studovaných bentonitů $k$ médi byla zanedbatelná. Korozní rychlosti byly v rádu desetin mikrometrů za rok. Nebyl pozorován žádný vliv složení pórového roztoku na korozni rychlost nebo složeni korozních produktu.

close packed in a coils. Two coils were exposed in each flask. Foils were weighed on analytical scales before and after the exposure. Experiments were carried out at laboratory temperature $\left(\mathrm{T}_{\mathrm{LAB}}\right)$. One sample from each flask was removed after 1 month exposure; the second after 4 months. Some samples were studied by means of X-ray diffraction (XRD). Finally, all samples were pickled in solution of sulfuric acid (5 wt.\%) for 5 minutes and weighed. Liquid parts of slurries were filtered and analysed by means of ion chromatography and $\mathrm{pH}$ meter.

\section{RESULTS AND DISCUSSION}

The swelling of bentonites resulted in different liquid portion of the slurry which was extracted for analyses (see Tab. 1). Bentonites BaM, Rokle and Sabenil provided significant volume of liquid part, B75 and Voltex significantly lower volume and G2M absorbed all water forming the gel part of the slurry. Therefore, $\mathrm{pH}$ and ion chromatography could not be performed in the G2M slurry. Values of $\mathrm{pH}$ were approximate measures of bicarbonates/carbonates content. Among other bentonites, the only exception was bentonite B75, which was activated during manufacture by addition of sodium carbonate. Major anion component of the 
slurry pore solution was sulphate. Almost all bentonites contained about $10^{-4} \mathrm{~mol} . \mathrm{dm}^{-3}$, amount of sulphates in Voltex was one order higher. Sabenil and Voltex had slightly higher content of chlorides, compared to the others. The significant differences were in nitrates. Concentrations in BaM, Voltex and B75 were measurable, but undetectable in Rokle and Sabenil.

The appearance of the samples and local XRD data are summarised in Fig. 1. All samples were attacked uniformly. Despite some localized precipitation of different corrosion products, especially on samples BaM, Rokle and Voltex, no penetration into the material was observed after the pickling procedure. The presence of tenorite and malachite under anaerobic conditions is of interest. Cuprous corrosion products are usually detected under such conditions. It was obviously independent on a content of nitrates, since Sabenil bentonite which was free of nitrates showed the highest content of tenorite after the exposure. This could be action of ferric cations leached from the bentonites, but their analysis in the slurry is extremely difficult. Content of malachite was also not related to the content of carbonates since the content of malachite on the surface of B75 sample was limited. Precipitation of corrosion products was probably influenced by the local composition of pore solution, which could not be analysed in the bulk.

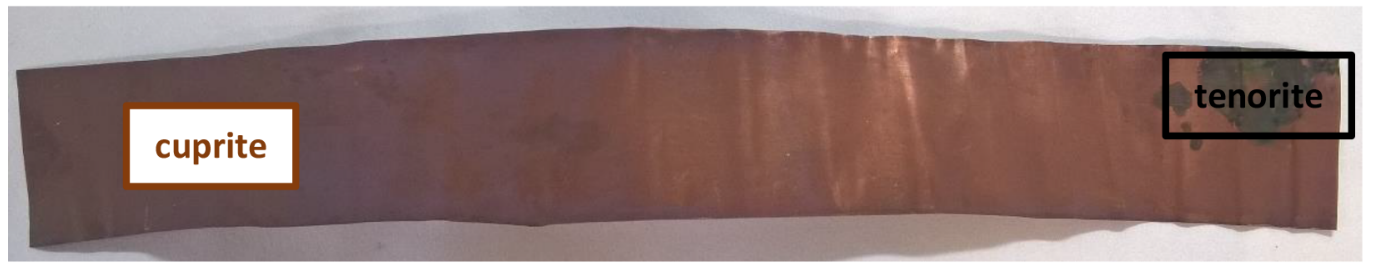

BaM

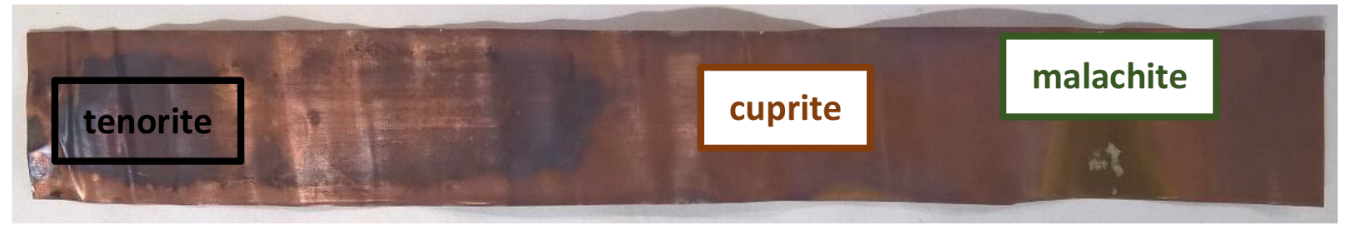

Rokle

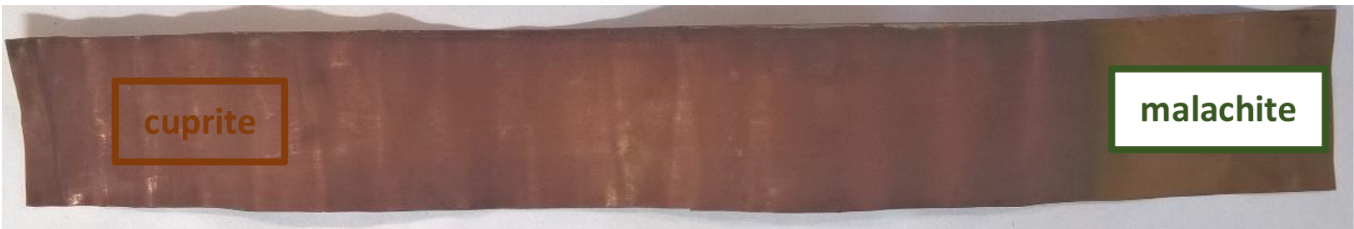

B75

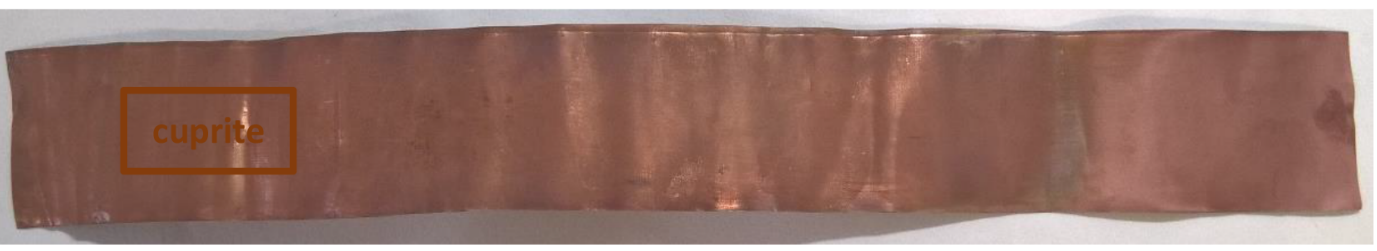

G2M

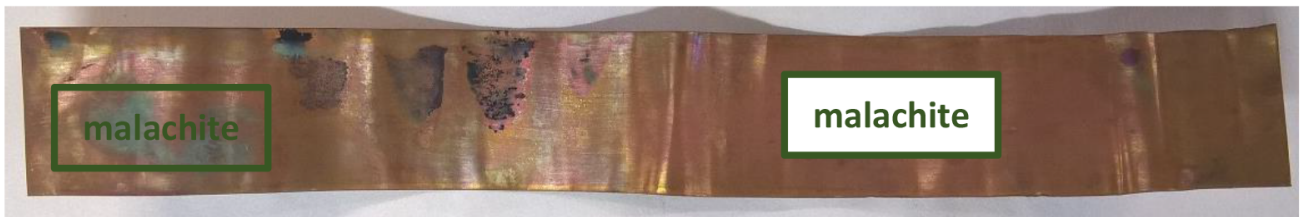

Voltex

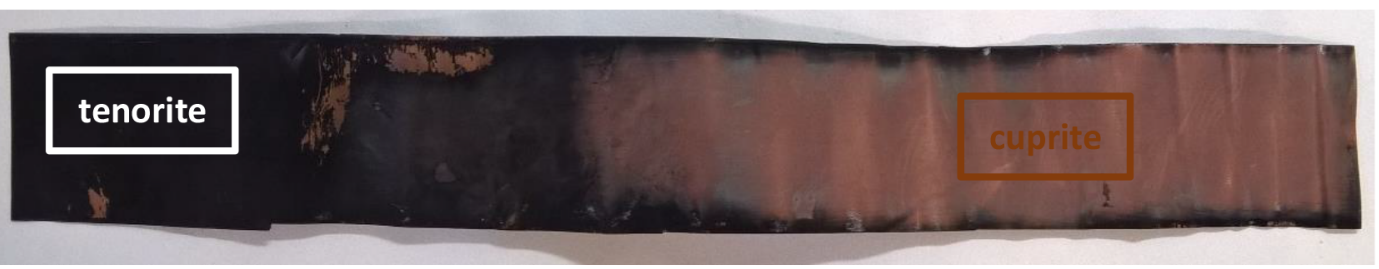

Sabenil

Fig. 1. Appearance of the samples after 4 month exposure and local XRD analyses

Obr. 1. Vzhled vzorků po 4 měsíční expozici a lokální rentgenově difrakční analýzy 
Tab. 1. Composition of slurry liquid part after the 4 month exposure / Složení kapalné části suspenzí po 4 měsični expozici

\begin{tabular}{|c|c|c|c|c|c|c|}
\hline \multirow{2}{*}{ Bentonite } & Vol. of liquid & \multirow{2}{*}{ pH } & fluoride & chloride & nitrate & sulphate \\
\hline & [ml] & & \multicolumn{4}{|c|}{$\left[\mathrm{mol} \mathrm{dm}^{-3}\right]$} \\
\hline $\mathrm{BaM}$ & 580 & 8.5 & $2.7210^{-5}$ & $7.0110^{-5}$ & $2.9010^{-5}$ & $1.8510^{-4}$ \\
\hline Rokle & 550 & 8.6 & $5.6710^{-5}$ & $6.0610^{-5}$ & $<4.8410^{-7}$ & $3.6310^{-4}$ \\
\hline B75 & 100 & 9.3 & $4.6710^{-5}$ & $8.6810^{-5}$ & $5.7910^{-5}$ & $1.6010^{-4}$ \\
\hline G2M & - & 8.3 & - & - & - & - \\
\hline Voltex & 200 & 8.6 & $6.9410^{-5}$ & $1.5710^{-4}$ & $8.3110^{-5}$ & $4.0010^{-3}$ \\
\hline Sabenil & 485 & 8.4 & $3.4410^{-5}$ & $1.9310^{-4}$ & $<4.8410^{-7}$ & $1.3010^{-4}$ \\
\hline
\end{tabular}

Tab. 2. Summary of the mass loss evaluation / Souhrn vyhodnoceni hmotnostnich úbytki

\begin{tabular}{|l|c|c|}
\hline \multirow{2}{*}{ Bentonite } & \multicolumn{2}{|c|}{ Corrosion rate $\left[\boldsymbol{\mu} \mathbf{m ~ a}^{-1}\right]$} \\
\cline { 2 - 3 } & $\mathbf{1}$ month & $\mathbf{4}$ months \\
\hline BaM & 0.35 & 0.27 \\
\hline Rokle & 0.35 & 0.43 \\
\hline B75 & 0.12 & 0.26 \\
\hline G2M & 0.31 & 0.32 \\
\hline Voltex & 0.39 & 0.32 \\
\hline Sabenil & 1.01 & 0.53 \\
\hline
\end{tabular}

Estimated mass loss corrosion rates are summarised in Tab. 2. All samples showed corrosion rate in order of tenths of $\mu \mathrm{m} . \mathrm{a}^{-1}$ after the 4 months of exposure. Influence of pore solution composition on dissolution rate within the short term exposure is rather negligible. It could become important in long-term exposures, when more voluminous corrosion products could seal the bentonite pore system efficiently, decreasing the transport ability and consequently the corrosion rate.

\section{CONCLUSIONS}

No significant effect of bentonite pore solution composition on corrosion rate was observed within 4 months exposure. In addition, no significant effect of the bulk bentonite pore solution on the composition of corrosion products was observed. There were most likely local compositions which played more important role in precipitation of corrosion products.

\section{Acknowledgement}

This work was supported by SÚRAO (Czech Radioactive Waste Repository Authority) under Project No. SO2013-088.

\section{REFERENCES}

1. Björkbacka, Å., et al., Radiation induced corrosion of copper for spent nuclear fuel storage. Radiation Physics and Chemistry 2013, 92, 80-86.

2. Björkbacka, $\AA$., et al., Role of the Oxide Layer in Radiation-Induced Corrosion of Copper in Anoxic Water. The Journal of Physical Chemistry C 2016, 120 (21), 11450-11455.

3. Bjorkbacka, A., et al., Kinetics and mechanisms of reactions between $\mathrm{H}_{2} \mathrm{O}_{2}$ and copper and copper oxides. Dalton Trans 2015, 44 (36), 16045-51.

4. King, F.; Kolar, M., Lifetime Predictions for Nuclear Waste Disposal Containers. Corrosion 2019 (available http://corrosionjournal.org/doi/pdf/10.5006/2994).

5. Rosborg, B., et al., Corrosion rate of pure copper in an oxic bentonite/saline groundwater environment. Corrosion Engineering, Science and Technology 2011, 46 (2), 148-152.

6. Hall, D. S.; Keech, P. G., An overview of the Canadian corrosion program for the long-term management of nuclear waste. Corrosion Engineering, Science and Technology 2017, 52 (S1), 2-5.

7. Kremer, E. P., Durability of the Canadian used fuel container. Corrosion Engineering, Science and Technology 2017, 52 (sup1), 173-177.

8. Standish, T., et al., Corrosion of Copper-Coated Steel High Level Nuclear Waste Containers under Permanent Disposal Conditions. Electrochimica Acta 2016, 211, 331-342.

9. Standish, T., et al., Synchrotron-Based Micro-CT Investigation of Oxic Corrosion of Copper-Coated Carbon Steel for Potential Use in a Deep Geological Repository for Used Nuclear Fuel. Geosciences 2018, 8 (10), 360.

10. Standish, T. E., et al., Galvanic corrosion of copper-coated carbon steel for used nuclear fuel containers. Corrosion Engineering, Science and Technology 2017, 1-5.

11. Stoulil, J., et al., Corrosion resistance of new powder metallurgy boron-containing stainless steel in the nuclear repository environment. Materials and Corrosion 2015, 66 (4), 342-346.

12. Stoulil, J., et al., Influence of temperature on corrosion rate and porosity of corrosion products of carbon steel in anoxic bentonite environment. Journal of Nuclear Materials 2013, 443 (1-3), 20-25.

13. Stoulil, J., et al., Hydrogen embrittlement of duplex stainless steel 2205 and TiPd alloy in a synthetic bentonite pore water. Corrosion 2019 (available http://corrosionjournal. org/doi/pdf/10.5006/2852). 
14. Stoulil, J., et al., 1D simulation of canister galvanic corrosion in saturated compacted bentonite. Materials and Corrosion 2018, 69 (9), 1163-1169.

15. Novikova, D., et al., Korozní chování oceli ČSN 422707.9 v zahuštěné syntetické pórové vodě bentonitu. Koroze a ochrana materiálu 2016, 60 (3), 68-73.

16. Stoulil, J., et al., Influence of heat transfer on corrosion behaviour of materials for radioactive waste canisters in synthetic bentonite pore water and bentonite suspension. Koroze a ochrana materiálu 2016, 60 (5), 139-143.

17. Stoulil, J.; Dobrev, D., Microbial corrosion of metallic materials in a deep nuclear-waste repository. Koroze a ochrana materiálu 2016, 60 (2), 60-67.

18. Stoulil, J., et al., Korozní chování mědi v prostředí vlhkého bentonitu Rokle B75. Koroze a ochrana materiálu 2014, 58 (2), 43-47. 